\title{
In vitro Sensitivity of Antagonistic Trichoderma atroviride to Herbicides
}

\author{
Patricia Helena Santoro $^{1 *}$, Silvia Akimi Cavaguchi ${ }^{2}$, Talita Moretto Alexandre ${ }^{3}$, Janaina \\ Zorzetti $^{3}$ and Pedro Manuel Oliveira Janeiro Neves ${ }^{3}$ \\ ${ }^{I}$ Área de Fitotecnia; Instituto Agronômico do Paraná; Londrina - PR - Brasil. ${ }^{2}$ Centro Nacional de Pesquisa de \\ Soja; Empresa Brasileira de Pesquisa Agropecuária; Londrina - PR - Brasil. ${ }^{3}$ Programa de Pós-Graduação em \\ Agronomia; Laboratório de Controle Microbiano; Universidade Estadual de Londrina; Londrina, PR - Brasil.
}

\begin{abstract}
Trichoderma atroviride was tested in vitro for its sensitivity to different herbicides. The dosages tested were recommended dosage $(R D)$, half dosage $(1 / 2 R D)$, and double dosage (2RD). Germination, colony-forming units $(C F U)$, radial growth, and spore production were evaluated. Carfentrazone-ethyl and sulfentrazone inhibited the germination at RD and 2RD. A reduction in the CFU was observed for glufosinate-ammonium, atrazine, carfentrazone-ethyl, diuron + paraquat dichloride, imazapyr, oxyfluorfen, and sulfentrazone at each of the tested dosages. Radial growth was influenced by ametryn, atrazine, carfentrazone-ethyl, oxyfluorfen, and sulfentrazone herbicides, with an $80 \%$ reduction of the colonial area. Spore production was affected by carfentrazone-ethyl, oxyfluorfen, and sulfentrazone with colonial area reductions of over 70\%. It was concluded that 2,4 D, clomazone, and imazapyr herbicides showed the least toxicity to $\mathrm{T}$. atroviride and should be used in the crops where the fungus has been applied for phytopathogen control.
\end{abstract}

Key words: Biological control, Compatibility, Conservative management, Antagonistic microorganisms, Plant pathogens

\section{INTRODUCTION}

In agricultural systems, biological control of plant diseases, weeds, and pests can be achieved by increasing the control agent through inundative application, or by preserving them by using the management strategies (Alves et al. 1998). One factor that reduces the effectiveness of biological control agents is the application of chemicals in the field. Therefore, selective products need to be used to preserve these agents.

Trichoderma atroviride has antagonistic properties based on their mycoparasitism, competition, and antibiotic mechanisms (Adams 1990). Trichoderma sp can be an alternative control to
Alternaria sp, Fusarium sp, and Sclerotinia sp in integrated disease management and organic crop production (Roco and Perez 2001; Abdullah et al. 2008; Jayalakshmi et al. 2008). Several studies have been conducted in vitro to evaluate the side effects of pesticides on the microorganisms used in insect biological control (Hirose et al. 2001; Neves et al. 2001; Silva and Neves 2005). However, little is known about the side effects of different herbicide groups on the development of Trichoderma $\mathrm{sp}$ in vitro. Since herbicides differ widely in chemical structure and functional groups, they can also differ in their effects on Trichoderma sp (Robert et al. 2008). Therefore, prior to applying Trichoderma as a biocontrol

*Author for correspondence: patriciasantoro@iapar.br 
agent, it is necessary to know the side effects of the chemicals used in crop protection.

\section{MATERIALS AND METHODS}

\section{Microorganisms}

The T. atroviride strain used (UEL 257) was isolated from the soil samples in Castro, Paraná, Brazil. The species was identified by sequencing the ITS region and processing it with TrichOKEY software from the International Subcommission on Trichoderma and Hypocrea taxonomy website (http://isth.info/). The fungus spores were grown in Petri dishes on potato dextrose agar (PDA) medium and kept in an incubator $\left(25 \pm 1{ }^{\circ} \mathrm{C}, 12\right.$-h photoperiod, and relative humidity of $75 \% \pm 10 \%$ ) for 10 days. The variables evaluated were spore germination, colony forming units (CFU), radial growth and spore production using a completely randomized experimental design with five replicates.

\section{Herbicides}

The side effects of 12 commercially available herbicides having different chemical groups with different modes of action were tested at three dosages: the recommended dosage (RD) that corresponded to the field dosage, half dosage $(1 / 2 R D)$, and double dosage (2RD) for spore germination and CFU. Only the RD was tested for the radial growth and spore production. The active ingredient (a.i.), formulation, and average recommended dosage (RD) for 200-L mixtures of the commercial products were as follows: $2,4 \mathrm{D}$ Agripec $^{\circledR}$, soluble liquid (SL), 2,4 D (867 g. $\mathrm{L}^{-1}$ a.i.), $\mathrm{RD}=1.5 \mathrm{~L}$; Atrazinax ${ }^{\circledR}$ 500, suspension concentrate $(\mathrm{SC})$, atrazine $\left(500 \mathrm{~g} \cdot \mathrm{L}^{-1}\right.$ a.i. $), \mathrm{RD}=$ $1.0 \mathrm{~L}$; Aurora $^{\circledR}$, concentrated emulsion (CE), carfentrazone-ethyl (400 g. $\mathrm{L}^{-1}$ a.i.), $\mathrm{RD}=15 \mathrm{~L}$; Boral $500^{\circledast}, \mathrm{SC}$, sulfentrazone $\left(500 \mathrm{~g} \cdot \mathrm{L}^{-1}\right.$ a.i. $), \mathrm{RD}$ $=1 \mathrm{~L}$; Contain $^{\circledR}, \mathrm{SL}$, imazapyr (266.3 g. $\mathrm{L}^{-1}$ a.i. $)$, $\mathrm{RD}=1.5 \mathrm{~L}$; Finale ${ }^{\circledR}, \mathrm{SL}$, glufosinate-ammonium (200 $\mathrm{L}^{-1}$ a.i. $), \mathrm{RD}=2 \mathrm{~L}$; $\mathrm{Gamit}^{\circledR}$, emulsifiable concentrate (EC), clomazone (500 g. $\mathrm{L}^{-1}$ a.i. $), \mathrm{RD}=$ $2 \mathrm{~L}$; Glifosato 480 Agripec, SL, glyphosate (480 $\mathrm{g} \cdot \mathrm{L}^{-1}$ a.i.), $\mathrm{RD}=2 \mathrm{~L}$; Goal $\mathrm{BR}^{\circledR}, \mathrm{CE}$, oxyfluorfen (240 g.L $\mathrm{L}^{-1}$ a.i. $), \mathrm{RD}=1.0 \mathrm{~L}$; Gramocil ${ }^{\circledR}, \mathrm{SC}$, diuron $\left(100 \mathrm{~g} \cdot \mathrm{L}^{-1}\right.$ a.i. $)+$ paraquat dichloride $\left(200 \mathrm{~g} \cdot \mathrm{L}^{-1}\right.$ a.i.), $\mathrm{RD}=2 \mathrm{~L}$; Herbipak $500 \mathrm{BR}^{\circledR}, \mathrm{SC}$, ametryn (500 g. $\mathrm{L}^{-1}$ a.i.), $\mathrm{RD}=1.5 \mathrm{~L}$; Premerlin $600^{\circledR}, \mathrm{EC}$, trifluralin $\left(600 \mathrm{~g} \cdot \mathrm{L}^{-1}\right.$ a.i. $), \mathrm{RD}=3 \mathrm{~L}$.
Effects of herbicides on germination, radial grout hans conidia production

To assess the germination, a $0.1 \mathrm{~mL}$ spore suspension $\left(1 \times 10^{6}\right.$ spores $\left.\mathrm{mL}^{-1}\right)$ in a $0.005 \%(\mathrm{v} / \mathrm{v})$ aqueous Tween-20 solution and $0.1 \mathrm{~mL}$ of each herbicide were sprayed on $2.5 \times 7.5 \mathrm{~cm}$ microscope slides with $3.0 \mathrm{ml}$ PDA medium. The evaluation was carried out $24 \mathrm{~h}$ after the contact, using an optical microscope (40x). Approximately 200 spores were observed and categorized as germinated, or non-germinated. The calculation of germination percentage was based on the total number of spores observed. To assess the CFU, a suspension $\left(1 \times 10^{3}\right.$ spores $\left.\mathrm{mL}^{-1}\right)$ in a $0.005 \%(\mathrm{v} / \mathrm{v})$ aqueous Tween-20 solution was sprayed on the Petri dishes (diameter, $9 \mathrm{~cm}$ ) containing the PDA medium. After $24 \mathrm{~h}, 0.1 \mathrm{~mL}$ of the herbicide was sprayed into the dish. The $24-\mathrm{h}$ period was necessary to allow germinated spores to bond to the medium; in earlier tests with the same products, the adjuvant action present in the formulations and the pressure exercised by the spraying caused the spores to agglomerate in parts of the dish, making it impossible to count the colonies. The colonies were counted $72 \mathrm{~h}$ after the contact with herbicides.

The radial growth and spore-production measurements were performed by spraying $0.1 \mathrm{~mL}$ of the product on each Petri dish with PDA medium, after which the fungus was inoculated on three equidistant points. In this study, only the recommended dosage (RD) was tested, considering that $\mathrm{CFU}$ was an indicator for the radial growth inhibition. On the $8^{\text {th }}$ day, the average colony area was calculated using the largest and smallest diameter measured for one randomly chosen colony in each dish. From these colonies, spore production was evaluated by cutting the center of the colony by using a circular punch $\left(2.26 \mathrm{~cm}^{2}\right)$. The culture discs with the fungus were suspended in $0.005 \%$ (v/v) aqueous Tween-20 solution and vortexed for $30 \mathrm{~s}$, after which spore concentrations were counted using a Neubauer chamber. The production was estimated based on the number of spores per $\mathrm{cm}^{2}$. The applications of fungus suspensions and product formulations were carried out with an Airbrush sprayer and a Fanen-Diapump compressor-vacuum at $1 \mathrm{kgf} \cdot \mathrm{cm}^{-1}$. All the plates were place in an incubator $\left(25 \pm 1{ }^{\circ} \mathrm{C}, 12 \mathrm{~h}\right.$ photoperiod, and relative humidity of $75 \% \pm 10 \%$ ). Five replicates were used for each herbicide concentration treatment and for the non-treated controls, in 
which water was substituted for chemicals. All the data were subjected to the analysis of variance (ANOVA) and the means were compared using Tukey's test at $5 \%$ probability. The mean values of germination, mycelial colony diameter and spore production, and the relative standard deviation in the presence of each herbicide were expressed as percentages in relation to the control.

\section{RESULTS AND DISCUSSION}

\section{Effects of Chemicals on Antagonist \\ Germination}

The herbicides applied at $1 / 2 \mathrm{RD}$ did not affect the germination of $T$. atroviride spores compared to the control, with viability above $87 \%$ (Table 1). At $\mathrm{RD}$ and $2 \mathrm{RD}$, only carfentrazone-ethyl and sulfentrazone inhibited the fungus germination, with a reduction of $56.6 \%$ and $71.2 \%$ for carfentrazone and $82.73 \%$ and $96.24 \%$ for sulfentrazone, respectively, compared to the control. By inhibiting the germination, these products could reduce multiplication of $T$. atroviride in the soil, and thus, reduce its control efficiency. These commercial herbicides should be avoided in the areas where an integrated diseasemanagement program by using $T$. atroviride was in use.

Table 1 - In vitro effect of herbicides at different dosages on spore germination and colony forming units (CFU) of Trichoderma atroviride.

\begin{tabular}{|c|c|c|c|c|c|c|c|}
\hline \multirow{2}{*}{$\begin{array}{c}\text { Product } \\
\text { Control }\end{array}$} & \multirow{2}{*}{$\frac{\text { Dose }^{(\text {a) }}}{-}$} & \multicolumn{2}{|c|}{ Germination (\%) } & \multirow{2}{*}{$\frac{\mathbf{I}^{(\mathrm{c})}}{-}$} & \multicolumn{2}{|l|}{ CFU } & \multirow{2}{*}{$\frac{I}{-}$} \\
\hline & & $98.00 \pm 0.87$ & $\mathrm{AB}$ & & $120.6 \pm 2.23$ & $\mathrm{~A}$ & \\
\hline \multirow{3}{*}{$2,4 \mathrm{D}$} & $1 / 2 R D$ & $91.90 \pm 0.97$ & $\mathrm{aAB}$ & -4.23 & $119.76 \pm 1.03$ & $\mathrm{aA}$ & -0.70 \\
\hline & RD & $85.70 \pm 2.26$ & $\mathrm{aB}$ & -10.66 & $114.96 \pm 1.53$ & $\mathrm{aAB}$ & -4.68 \\
\hline & 2DR & $90.50 \pm 1.84$ & $\mathrm{aAB}$ & -5.82 & $93.84 \pm 1.67$ & $\mathrm{bBC}$ & -22.19 \\
\hline \multirow{3}{*}{ ametryn } & $1 / 2 \mathrm{RD}$ & $99.40 \pm 0.50$ & $\mathrm{aA}$ & 3.31 & $119.52 \pm 1.29$ & $\mathrm{aA}$ & -0.90 \\
\hline & RD & $99.90 \pm 0.83$ & $\mathrm{aA}$ & 3.73 & $119.52 \pm 1.54$ & $\mathrm{aA}$ & -0.90 \\
\hline & 2DR & - & - & - & $103.20 \pm 1.31$ & $\mathrm{bB}$ & -14.43 \\
\hline \multirow{3}{*}{ glufosinate-ammonium } & $1 / 2 R D$ & $93.90 \pm 0.46$ & $\mathrm{aAB}$ & -2.36 & $78.96 \pm 0.88$ & $\mathrm{abF}$ & -34.53 \\
\hline & RD & $95.60 \pm 0.92$ & $\mathrm{aAB}$ & -0.58 & $73.92 \pm 0.81$ & $\mathrm{aD}$ & -38.71 \\
\hline & 2DR & $89.30 \pm 2.84$ & $\mathrm{aAB}$ & -7.06 & $79.92 \pm 1.04$ & $\mathrm{bD}$ & -33.73 \\
\hline \multirow{3}{*}{ atrazine } & $1 / 2 R D$ & $96.20 \pm 0.19$ & aAB & 0.00 & $110.64 \pm 1.16$ & $\mathrm{aB}$ & -8.26 \\
\hline & RD & $96.20 \pm 0.19$ & $\mathrm{aAB}$ & 0.81 & $109.20 \pm 1.46$ & $\mathrm{aB}$ & -9.45 \\
\hline & 2DR & - & - & - & $91.92 \pm 1.11$ & $\mathrm{bC}$ & -23.78 \\
\hline \multirow{3}{*}{ carfentrazone-ethyl } & $1 / 2 R D$ & $93.50 \pm 1.00$ & aAB & -2.78 & $0.48 \pm 0.48$ & $\mathrm{bG}$ & -99.60 \\
\hline & RD & $40.70 \pm 6.61$ & $\mathrm{bC}$ & -56.64 & $0.48 \pm 0.29$ & $\mathrm{bE}$ & -99.60 \\
\hline & 2DR & $26.40 \pm 3.35$ & $\mathrm{cC}$ & -71.22 & $110.16 \pm 2.05$ & $\mathrm{aB}$ & -8.66 \\
\hline \multirow{3}{*}{ clomazone } & $1 / 2 R D$ & $92.80 \pm 3.10$ & aAB & -3.43 & $100.08 \pm 0.81$ & $\mathrm{bCDE}$ & -17.01 \\
\hline & RD & $97.10 \pm 1.73$ & $\mathrm{aA}$ & 0.97 & $119.52 \pm 1.04$ & $\mathrm{aA}$ & -0.90 \\
\hline & 2DR & $92.80 \pm 1.69$ & $\mathrm{aAB}$ & -3.44 & $120.00 \pm 2.04$ & $\mathrm{aA}$ & -0.50 \\
\hline \multirow{3}{*}{ diuron + paraquat dichloride } & $1 / 2 \mathrm{RD}$ & $91.20 \pm 2.86$ & $\mathrm{aAB}$ & -5.10 & $100.56 \pm 1.03$ & $\mathrm{aCD}$ & -16.62 \\
\hline & RD & $95.30 \pm 0.67$ & $\mathrm{aAB}$ & -0.94 & $0.24 \pm 0.24$ & $\mathrm{bE}$ & -99.80 \\
\hline & 2DR & $87.60 \pm 2.27$ & $\mathrm{aAB}$ & -8.81 & $0.48 \pm 0.48$ & $\mathrm{bD}$ & -99.60 \\
\hline \multirow{3}{*}{ glyphosate } & $1 / 2 R D$ & $95.70 \pm 2.17$ & aAB & -0.54 & $106.32 \pm 1.72$ & bABC & -11.84 \\
\hline & RD & $96.30 \pm 2.30$ & $\mathrm{aAB}$ & 0.09 & $118.32 \pm 1.72$ & bABC & -1.89 \\
\hline & 2DR & $84.00 \pm 1.33$ & bB & -12.44 & $119.52 \pm 1.29$ & $\mathrm{aA}$ & -0.90 \\
\hline \multirow{3}{*}{ imazapyr } & $1 / 2 R D$ & $93.80 \pm 0.28$ & aAB & -2.43 & $93.12 \pm 1.04$ & $\mathrm{bDE}$ & -22.79 \\
\hline & RD & $94.00 \pm 0.48$ & $\mathrm{aAB}$ & -2.26 & $101.52 \pm 0.72$ & $\mathrm{aC}$ & -15.82 \\
\hline & 2DR & $86.20 \pm 3.05$ & $\mathrm{aAB}$ & -10.20 & $75.12 \pm 1.44$ & $\mathrm{cC}$ & -37.71 \\
\hline \multirow{3}{*}{ oxyfluorfen } & $1 / 2 R D$ & - & - & - & $0.48 \pm 0.48$ & $\mathrm{aG}$ & $\begin{array}{l}-99.60 \\
\end{array}$ \\
\hline & RD & - & - & - & $0.24 \pm 0.24$ & $\mathrm{aE}$ & -99.80 \\
\hline & 2DR & - & - & - & $0.00 \pm 0.00$ & $\mathrm{aD}$ & -100.00 \\
\hline \multirow{3}{*}{ sulfentrazone } & $1 / 2 \mathrm{RD}$ & $87.40 \pm 2.86$ & $\mathrm{aB}$ & -8.98 & $0.48 \pm 0.48$ & $\mathrm{bE}$ & -99.60 \\
\hline & RD & $15.10 \pm 5.57$ & $\mathrm{bD}$ & -82.73 & $0.48 \pm 0.48$ & $\mathrm{bE}$ & -99.60 \\
\hline & 2DR & $1.95 \pm 1.54$ & $\mathrm{cD}$ & -96.24 & $79.92 \pm 1.63$ & $\mathrm{aD}$ & -33.73 \\
\hline \multirow{3}{*}{ trifluralin } & $1 / 2 \mathrm{RD}$ & - & - & - & $96.48 \pm 1.54$ & bDE & -20.00 \\
\hline & RD & - & - & - & $119.76 \pm 0.88$ & $\mathrm{aA}$ & -0.70 \\
\hline & 2DR & - & - & - & $119.52 \pm 1.29$ & $\mathrm{aA}$ & -0.90 \\
\hline CV (\%) & & 6.12 & & & 4.17 & & \\
\hline
\end{tabular}


When comparing the different dosages of a given product, differences in the germination were significant for carfentrazone-ethyl, glyphosate, and sulfentrazone. A correlation between the dosage and germination inhibition was observed, but for glyphosate, no difference was observed between $1 / 2 \mathrm{RD}$ and $\mathrm{RD}$. This correlation indicated that elevated dosages or successive applications of the herbicides that has led to cumulative effects of the active ingredients should be avoided in the areas where $T$. atroviride was utilized. Similar results were observed by Morjan et al. (2002), where spore germination and radial growth of Beauveria bassiana, Metarhizium anisopliae, Nomuraea rileyi, and Neozygites floridana were not affected by glyphosate when exposed to a concentration of $0.96 \%$ active ingredient. However, the results for fungicidal activity might vary due to differences in glyphosate formulations (Morjan et al. 2002). Germination could not be evaluated in the treatments with ametryn and atrazine at $2 \mathrm{RD}$ and for all the dosages of oxyfluorfen and trifluralin due to difficulty in observing the spores. These formulations contained the particles that could be confused with, or that could cover the spores in the culture medium.

\section{Effects of Chemicals on Antagonist CFU}

For the three doses tested, a reduction in CFUs was observed for glufosinate-ammonium, atrazine, carfentrazone-ethyl, diuron + paraquat dichloride, imazapyr, oxyfluorfen, and sulfentrazone compared to the control (Table 1). However, none of these products reduced the germination at the lowest dosage. This could be related to the higher chemical resistance of the spores compared to that of mycelia. Because spores are dissemination structures, they are more adapted to resist the stressors compared to vegetative cells, which are probably less resistant. The evaluation of CFU is extremely important. When there is high germination and low $\mathrm{CFU}$, the products are toxic to the fungus during the vegetative growth stage. On the other hand, low germination and high CFU indicate that germination might have been delayed but that the development of the fungus was not affected (Silva and Neves 2005).

The herbicide that most affected the CFU was oxyfluorfen, with more than $90 \%$ reductions at all the dosages (Table 1). For the treatments with ametryn and atrazine at $2 \mathrm{RD}$, and for all the dosages of trifluralin, it was not possible to evaluate the germination due to difficulty in detecting the spores. However, the $\mathrm{CFU}$ values obtained were $>91$ colonies with $<24 \%$ reduction compared to those in the control. This result confirmed that these treatments caused low germination inhibition in $T$. atroviride, while for oxyfluorfen, the high reduction in CFU showed that the fungus germination might have been affected at all the dosages. Ghannoum et al. (1989) observed that trifluralin did not affect the growth of $T$. viride, but that paraquat delayed its growth. Still, for CFU, distinct sensibility was observed when comparing the different dosages. For 2,4 D, ametryn, atrazine, diuron + paraquat dichloride, and imazapyr, increasing dosage reduced CFU, especially when 2DR was used. On the other hand, trifluralin, sulfentrazone, glyphosate, and carfentrazone were more toxic to the fungus at $1 / 2 R D$ and RD. Kumari et al. (2008) observed that trifluralin reduced the efficiency of $T$. viride at controlling diseases that caused damping off in cotton seedlings.

\section{Effects of Chemicals on Radial Growth}

The radial growth of $T$. atroviride was not affected by clomazone, glyphosate, or imazapyr compared to the control (Table 2). For glyphosate, the values obtained in the present study did not agree with those found by Meriles et al. (2006), who observed inhibition of the radial growth in Trichoderma sp when the herbicide was mixed with the culture medium.

Some herbicides may favor Trichoderma $\mathrm{sp}$ development. For instance, Creswell and Curl (1982) found that norflurazon significantly increased $T$. harzianum growth when added to the liquid medium. Nevertheless, radial growth of the fungus showed more sensitivity for ametryn, atrazine, carfentrazone-ethyl, oxyfluorfen, and sulfentrazone, reducing the colony area $>80 \%$ compared to the control. With the exception of ametryn, these products had the highest levels of CFU inhibition at $1 / 2 \mathrm{RD}$ and $\mathrm{RD}$, showing a correlation between these variables. Diuron + paraquat dichloride, which reduced the CFU by more than $99 \%$, reduced $23.98 \%$ of radial growth at the RD. This result allowed the hypothesis that radial growth was delayed during the colony formation. However, an adaptation of the fungus to the product, or gradual degradation of the product in the culture medium allowed the fungus to continue growth during the eight days of exposure. 
Table 2 - In vitro effects of herbicides on radial growth (VG) and spore production (SP) of Trichoderma atroviride.

\begin{tabular}{|c|c|c|c|c|c|c|}
\hline Product & VG $\left(\mathrm{cm}^{2}\right)^{(\mathbf{a})}$ & & $\mathbf{I}^{(\mathbf{b})}$ & $\mathrm{SP}\left(\times 10^{8}\right.$ & & I \\
\hline Control & $5.11 \pm 3.05$ & $\mathrm{a}$ & - & $7.39 \pm 1.98$ & $\mathrm{ab}$ & - \\
\hline $2,4 \mathrm{D}$ & $3.64 \pm 0.19$ & $\mathrm{c}$ & -28.77 & $7.10 \pm 0.43$ & $a b c$ & -3.92 \\
\hline ametryn & $0.38 \pm 0.05$ & $\mathrm{~d}$ & -92.56 & $5.06 \pm 0.49$ & cde & -31.53 \\
\hline glufosinate-ammonium & $3.25 \pm 0.25$ & $\mathrm{c}$ & -36.40 & $4.90 \pm 0.52$ & de & -33.69 \\
\hline atrazine & $0.83 \pm 0.17$ & $\mathrm{~d}$ & -83.76 & $4.42 \pm 0.38$ & $\mathrm{e}$ & -40.19 \\
\hline carfentrazone-ethyl & $1.01 \pm 0.29$ & $\mathrm{~d}$ & -80.23 & $2.07 \pm 0.37$ & $\mathrm{f}$ & -71.99 \\
\hline clomazone & $5.28 \pm 0.30$ & $\mathrm{a}$ & 3.33 & $7.05 \pm 0.14$ & abcd & -4.60 \\
\hline diuron + paraquat dichloride & $3.68 \pm 0.23$ & bc & -27.98 & $6.11 \pm 0.48$ & bcde & -17.32 \\
\hline glyphosate & $5.75 \pm 0.36$ & $\mathrm{a}$ & 12.52 & $4.48 \pm 0.82$ & $\mathrm{e}$ & -39.38 \\
\hline imazapyr & $4.83 \pm 0.07$ & $\mathrm{ab}$ & -5.48 & $8.45 \pm 0.40$ & $\mathrm{a}$ & 14.34 \\
\hline oxyfluorfen & $0.52 \pm 0.10$ & $\mathrm{~d}$ & -89.82 & $0.94 \pm 0.05$ & $\mathrm{f}$ & -87.28 \\
\hline sulfentrazone & $0.94 \pm 0.16$ & $\mathrm{~d}$ & -81.60 & $2.07 \pm 0.31$ & $\mathrm{f}$ & -71.99 \\
\hline trifluralin & $3.49 \pm 0.29$ & $\mathrm{c}$ & -31.70 & $6.04 \pm 0.59$ & bcde & -18.27 \\
\hline $\mathrm{VG}(\%)$ & 17.68 & & & 19.63 & & \\
\hline
\end{tabular}

\section{Effects of Chemicals on Spore Production}

Spore production in the fungus did not differ from that of the control when the fungus was in contact with 2,4 D, clomazone, diuron + paraquat dichloride, imazapyr, and trifluralin. Inhibition of spore production was observed for ametryn, glufosinate-ammonium, atrazine, diuron + paraquat dichloride, glyphosate, and trifluralin (Table 2). However, ametryn and atrazine corresponded to significantly lower radial growth than that by the other herbicides, which showed that the proportional inhibition of radial growth and spore production differed. The products containing carfentrazone-ethyl, oxyfluorfen, and sulfentrazone promoted low spore production, confirming their toxicity to $T$. atroviride.

In vitro tests have the advantage of maximum exposure of microorganisms to the chemicals of interest, which does not occur in the field studies, where various factors can interfere with the exposure, or contact (Alves et al. 1998). For this reason, the selectivity obtained in vitro offers a greater degree of assurance that the product will not affect the biological agent when used in the field. When they are applied in the field, many products facilitate an increase in Trichoderma sp, showing that their effects are not always antagonistic. In some cases, the fungus can use the product, or subproducts that result from the degradation for its growth and development (Das et al. 2003).

Considering all the variables evaluated in this study, the fungus was less sensitive to the herbicides 2,4 D, clomazone, and imazapyr. Therefore, it would preferable to use these herbicides for weed control in the areas were $T$. atroviride is applied, or when the purpose is to conserve the natural inocula in the field for conservative biological control. Studies on the effects of agricultural chemicals on the biological control agents are necessary before beginning the integrated management in the areas where both will be used. Selectivity will contribute to the preservation of the biological agents, encouraging environmental equilibrium. The products atrazine, carfentrazone-ethyl, oxyfluorfen, and sulfentrazone can be considered the most toxic and should be avoided in the areas where integrated disease management is performed using $T$. atroviride, or the areas using conservative biological control.

\section{CONCLUSION}

It was concluded that the selectivity of the different herbicides tested under the experimental conditions could contribute to the development of integrated disease management programs.

\section{ACKNOWLEDGMENTS}

The authors would like to thank Dr. Ricardo Harakava of the Phytopathological Biochemistry Laboratory of São Paulo Biologic Institute for identifying the T. atroviride species; Professor Dr. José Carlos Vieira, Agronomy Engineer, Londrina State University; and Célio Roberto Ferreira Leite for his help in choosing the herbicide formulas and providing the herbicides. 


\section{REFERENCES}

Abdullah MT, Ali NY, Suleman P. Biological control of Sclerotinia sclerotiorum (Lib.) de Bary with Trichoderma harzianum and Bacillus amyloliquefaciens. Crop Prot. 2008; 27: 1354-1359.

Adams PB. The potential of mycoparasites for biological control of plant diseases. Annu Rev Phytopathol. 1990; 28: 59-72.

Alves SB, Moino Junior A, Almeida JEM. Produtos fitossanitários e entomopatógenos. In: Alves SB, editor. Controle Microbiano de Insetos. Piracicaba: Fealq; 1998. p. 21-38.

Creswell TC, Curl EA. Effects of some herbicides on Rhizoctonia solani and Trichoderma harzianum. Phytopathology. 1882; 72: 356-359.

Das AC, Chakravarty A, Sukul P, Mukherjee D. Influence and persistence of phorate and carbofuran insecticides on microorganisms in rice field. Chemosphere. 2003; 53: 1033-1037.

Ghannoum MA, Afzal M, Hasan RAH, Dhami MSI. Variation in growth and fatty acid contents of Trichoderma viride induced by herbicides. J Environ Sci Health. 1989; 24: 957-966.

Hirose E, Neves PMOJ, Zequi JAC, Martins LH, Peralta $\mathrm{CH}$, Moino Junior A. Effect of biofertilizers and neem oil on the entomopathogenic fungi Beauveria bassiana (Bals.) Vuill. and Metarhizium anisopliae (Metsch.) Sorok. Braz Arch Biol Technol. 2001; 44: 419-423.

Jayalakshmi SK, Benagi VI, Usharani S, Mahalinga DM. Efficacy of native isolates of Trichoderma spp. against chickpea wilt caused by Fusarium oxysporum f. sp. ciceris. Crop Research. 2008: 36: 310-312.
Kumari M, Hooda I, Karwasra SS. Effect of pre-plant herbicides on the biocontrol efficacy of Trichoderma spp. against Rhizoctonia solani. J Cotton Res Dev. 2008; 22: 221-224.

Meriles JM, Vargas MG, Haro S, March RJ, Guzma GJ. Glyphosate and previous crop residue effect on deleterious and beneficial soil-borne fungi from a peanut-corn-soybean rotations. J Phytopathol. 2006; 154: 309-316.

Morjan WE, Pedigo LP, Lewis LC. Fungicidal effects of glyphosate and glyphosate formulations on four species of entomopathogenic fungi. Environ Entomol. 2002; 31: 1206-1212.

Neves PMOJ, Hirose E, Tchujo PT, Moino Junio A. Compatibility of entomopathogenic fungi with neonicotinoids insecticides. Neotrop Entomol. 2001; 30: 263-268.

Robert GP, York Alan AC, Jordan DL. Comparison of glyphosate products in glyphosate-resistant cotton (Gossypium hirsutum) and corn (Zea mays). Weed Technol. 2008; 19: 796-802.

Roco A, Perez LM. In vitro biocontrol activity of Trichoderma harzianum on Alternaria alternata in the presence of growth regulators. Electronic $J$ Biotechnol. 2001; 4: 1-6.

Silva RZ, Neves PMOJ. Techniques and parameters used in compatibility tests between Beauveria bassiana (Bals) Vuill. and in vitro phytosanitary products. Pest Manag Sci. 2005; 61: 667-674.

Received: January 15, 2013; Accepted: November 25, 2013. 